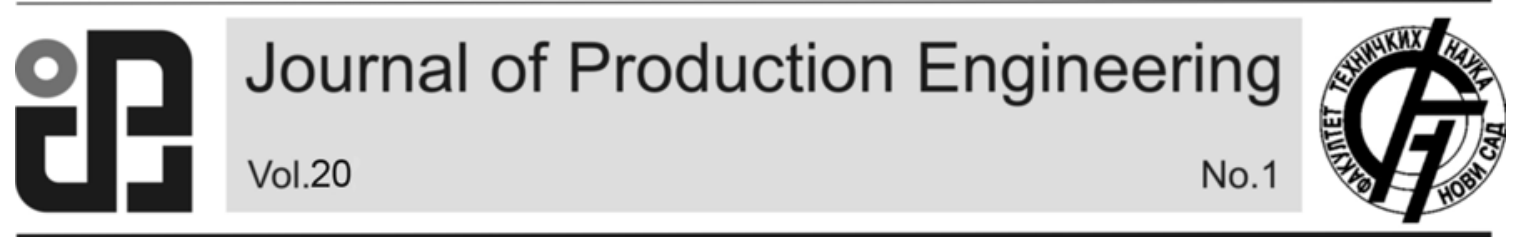

JPE (2017) Vol.20 (1)

\author{
Siva Kumar, B., Charan Theja, P.
}

Original Scientific Paper

\title{
STUDY OF WEAR \& MICROSTRUCTURAL BEHAVIOR OF HYBRID ALUMINIUM METAL MATRIX COMPOSITE MANUFACTURED BY STIR CASTING TECHNIQUE
}

\author{
Received: 27 February 2017 / Accepted: 10 May 2017
}

\begin{abstract}
Aluminium is one of the most widely used metals due to its desirable physical, chemical and mechanical properties and it characterizes an important category of technological materials. Because of its high strength-to weight ratio, besides other desirable properties e.g. high corrosion resistance, desirable appearance, nonmagnetic, non-sparking, non-toxic, ease of fabrication and high thermal and electrical conductivities, aluminium and its alloys are used in a wide variety of industrial applications. These properties led also to the association of aluminium and its alloys with transportation mainly with aircraft and space vehicles, containers and packaging and electrical transmission lines, construction and building. Nowadays Al-based composites are used due to their superior mechanical properties. The reinforcements are ceramic, metallic and non-metallic used in the form of particles, fibers, and laminates. The reinforcements added to MMC will improve the properties of the composite like yield strength, hardness, density and wear behavior. There are several studies done on the non-metallic and ceramic reinforcements. This paper attempts to study the different combination of reinforcing materials used in the processing of hybrid aluminium matrix composites and how it affects the wear performance \& Microstructure of the materials.
\end{abstract}

Key words: Composite, Hybrid Aluminium Metal Matrix Composite, Reinforcement, Stir Casting.

Studija habanja \& mikrostrukturno ponašanje kompozita hibridnih aluminijuma sa metalnom osnovom proizvodenih uzburkanim livenjem. Aluminijum je jedan od najšire korišćenih metala zbog poželjanih fizičkih, hemijskih i mehaničkih svojstava i on spada u važnu kategoriju tehnoloških materijala. Zbog svoje visoke čvrstoće za određenu težinu, pored drugih poželjnih osobina npr. visoka otpornost na koroziju, poželjan izgled, nemagnetičnost, ne varničnost, netoksičanost, lako se obrađuje i ima visoku termičku i električnu provodljivost, shodno tome aluminijum i njegovih legura se koriste u raznim industrijskim oblastima. Ove osobine su dovele da se danas aluminijum i njegove legure koriste pri izradi transportnih sredstva, uglavnom aviona $i$ svemirskih vozila, kontejnera i ambalaža i izgradnju električnih dalekovoda, i izradu kompozita. Kompoziti bazirani na aluminijumul se koriste zbog njihovih superiornih mehaničkih osobina. Pojačavaju se pomoću keramike, metala i nemetala u obliku čestica, vlakana, i laminata. Pojačanje je dodato u metalnu osnovu i poboljšava svojstva kompozita kao što su tečenja, tvrdoća, gustina $i$ habanje. Postoji nekoliko studija koje su rađene sa nemetalnim $i$ keramičkim pojačanjima. Ovaj rad pokušava da prouči različitu kombinaciju ojačanih materijala koji se koriste u izradi hibridnih aluminijumskih matrica kompozita i kako to utiče na performanse tj. habanje \& mikrostrukturu materijala. Ključne reči: Kompoziti, hibridni kompoziti aluminijuma sa metalnom matricom, armatura, uzburkano livenje.

\section{INTRODUCTION}

In the last two decades research has shifted from monolithic materials to composite materials to meet the global demand for light weight, high performance, environmental friendly, wear and corrosion resistant materials. Metal Matrix Composites (MMC) are suitable for applications requiring combined strength, thermal conductivity, damping properties and low coefficient of thermal expansion with lower density. In the field of automobile, MMC's are used for pistons, brake drum and cylinder block because of better corrosion resistance and wear resistance.

Manufacturing of MMC's has several challenges like porosity formation, poor wettability and improper distribution of reinforcement. Achieving uniform distribution of reinforcement is the foremost important work. A new technique of manufacturing cast Aluminium Matrix Composite has been proposed to improve the wettability between alloy and reinforcement. In this, all the materials are placed in graphite crucible and heated in an inert atmosphere until the matrix alloy is melted and followed by two step stirring action to obtain uniform distribution of reinforcement. The manufacturing techniques of MMCs play a major role in the improvement of mechanical and tribological properties.. The size and type of reinforcement also has a significant role in determining the mechanical and tribological properties of the composites.

There is a growing interest worldwide in manufacturing hybrid metal matrix composites [HMMCs] which possesses combined properties of its reinforcements and exhibit improved physical, mechanical and tribological properties.

Aluminium Metal Matrix Composite (AMMC) is competent material in the industrial world. Due to its excellent mechanical properties it is widely used in aerospace, automobiles, marine, etc. The aluminium matrix is getting strengthened when it is reinforced 
with the hard ceramic particles such as $\mathrm{B}_{4} \mathrm{C}, \mathrm{SiC}, \mathrm{TiC}$, $\mathrm{Al}_{2} \mathrm{O}_{3}$ etc. Aluminium alloys are still the subject of intense studies, as their low density gives additional advantages in several applications. These alloys have started to replace cost iron and bronze to manufacture wear resistance parts.

\section{LITERATURE SURVEY}

A lot of contributions (or) studies are existing for the manufacturing of Hybrid Aluminium Metal Matrix Composites (HAMMC) by reinforcing Aluminium Metal with different combination of materials (Reinforcements). Some of them are reviewed and discussed below:

E. Subbarao, N. Ramanaiah [1] This study is aimed in evaluating the mechanical properties of aluminium metal matrix composite (AMMC). AMMCs were made, AA6061 as matrix material and $\mathrm{B}_{4} \mathrm{C}$ as reinforcement material, through stir casting method. AMMCs with varying percentage by different wt. $\%$, $1 \%, 2 \%, 3 \%, 4 \%, 5 \% \mathrm{~B}_{4} \mathrm{C}$ were fabricated. It was noticed that, mechanical properties are increase with the increase in wt. $\%$ of the reinforcement up to $4 \%$ $\mathrm{B}_{4} \mathrm{C}$ further addition there is a diminution in both the conditions (as cast and heat treatment condition). It was also thought-out that $4 \% \mathrm{~B}_{4} \mathrm{C}$ composite shows better mechanical (hardness, yield strength and tensile strength) properties and low \% of elongation than all other compositions in both the conditions. Optical micrographs and SEM micrographs revealed that the $\mathrm{B}_{4} \mathrm{C}$ particles were well distributed in the Aluminium matrix in heat treatment condition.

N. Venkat Kishore, Dr. K. Venkata Rao [2] In thist study Aluminum alloy (A356/LM25) and Boron Carbide $\left(\mathrm{B}_{4} \mathrm{C}\right)$ were taken as matrix and reinforcement respectively. The Fabrication, mechanical and metallurgical investigation of Aluminum alloy (A356/LM25) and Boron Carbide $\left(\mathrm{B}_{4} \mathrm{C}\right)$ composites containing the three different weight percentages $5 \%$, $7.5 \%$ and $10 \%$ of $\mathrm{B}_{4} \mathrm{C}$ by means of Two Step-Mixing method of Stir Casting Technique. Further it was found from the experimentation is that the developed method is quite successful to obtain uniform dispersion of reinforcement in the matrix. The results indicated that the wear rate decreases and an increasing trend of hardness and tensile strength with increase in weight percentage of $\mathrm{B}_{4} \mathrm{C}$ have been observed. The internal structure of the composite is observed using Optical Metallurgical Microscope. It is observed that $\mathrm{B}_{4} \mathrm{C}$ particles are dispersed uniformly in the aluminum matrix for all wt $\%$ and also Grain refinement was increased by increasing in percentage of Boron Carbide $\left(\mathrm{B}_{4} \mathrm{C}\right)$ reinforcement in the Aluminum (LM25) Matrix.

M.D.Antony Arul Prakash, M.Arockia Jaswin [3] In this project silicon carbide and boron carbide particulate reinforced aluminium alloy matrix composites are produced by stir casting process by varying the particulate addition by weight fraction of $\mathrm{Al}(90 \%), \mathrm{SiC}(5 \%, 6.5 \%, 8 \%)$ and $\mathrm{B}_{4} \mathrm{C}(5 \%, 3.5 \%$, $2 \%$ ). Characterization study was made by SEM and optical microscopic analysis, the result predict that the dispersion of the $\mathrm{SiC}$ and $\mathrm{B}_{4} \mathrm{C}$ particles are equal in all over the specimens and also an increase in the particles cluster corresponding to an increase in the processing temperatures.

Gaurav Mahajan, Nikhil Karve, Uday Patil, P. Kuppan, K. Venkatesan [4] In this paper an effort has been made to fabricate a hybrid metal matrix composite, silicon carbide and titanium diboride reinforced in Al 6061 matrix using stir casting method. Microstructure and mechanical properties such as micro hardness and wear are studied for various compositions of reinforcements, $10 \% \mathrm{SiC}$ and $2.5 \%$, $5 \%$ and $10 \% \mathrm{TiB}$. The results indicate that the hardness value increases with the addition of the $\mathrm{SiC}$ and $\mathrm{TiB}$ reinforcements to matrix Al6061, while the wear resistance increases up to certain amount and reduces drastically when crossed the transition load.

A. Singh, A. S. Rana, N. Bala [5] In this study, aluminium composite with $5 \%$ reinforcement of $\mathrm{Al}_{2} \mathrm{O}_{3}$ + fly-ash was prepared using a cost effective stir casting technique. Testing of wear behavior was done on pin on disc apparatus at a normal load of $40 \mathrm{~N}$ and sliding velocities of $0.8 \mathrm{~m} / \mathrm{sec}$ and $1 \mathrm{~m} / \mathrm{sec}$. The fabricated composites showed improvement in wear resistance over the monolithic aluminum metal.

T. Raviteja, N. Radhika, R. Raghu [6] ) The present study was made to understand the fabrication and mechanical properties of $\mathrm{Al}-\mathrm{Si} 12 \mathrm{Cu} / \mathrm{B}_{4} \mathrm{C}$ Metal Matrix Composites. The composites were fabricated by reinforcing $\mathrm{B}_{4} \mathrm{C}$ particles with varying wt $\%$ of $2,4,6$, 8 and 10 , using stir casting process. The microstructure was examined on the composite specimens using optical microscope to confirm the homogeneous dispersion of reinforcement particles in the matrix. Mechanical properties such as hardness and tensile strength were tested on the composite using Brinell hardness tester and computerized Universal Testing Machine respectively. The results revealed that the $\mathrm{B}_{4} \mathrm{C}$ particles were homogeneously distributed in the composite. The hardness and tensile test results showed that, by increasing wt \% of reinforcement particles in the matrix, hardness and tensile strength of the composites was improved to $6.97 \%$ and $33 \%$ respectively compare to base alloy.

T. Thirumalai, R. Subramanian, S. Kumaran, S. Dharmalingam, S. S. Rama Krishnan [7] Aluminum matrix composites reinforced with up to $12 \mathrm{wt} \% \mathrm{~B}_{4} \mathrm{C}$ and $3 \mathrm{wt} \% \mathrm{Gr}$ particulates are investigated in the present study. Hybrid composites exhibit better wear characteristics compared to aluminium alloy. Wear tests were carried out with loads varying from 10 to $40 \mathrm{~N}$ and sliding distances of 500 and $1000 \mathrm{~m}$ with a constant sliding speed of $1 \mathrm{~m}$ per second. An interaction between load and sliding distance was observed in the composites which may be attributed to the presence of Gr particulates. Decrease in wear with an increase in speed and vice versa were observed with both load and sliding distance. Hardness of the composites measured using Vicker's Hardness Tester indicated that hardness increased with increasing percent of $\mathrm{B}_{4} \mathrm{C}$ reinforcement while addition of $\mathrm{Gr}$ imparted the lubrication effect in the composites.

Md. Habibur Rahman, H. M. Mamun Al Rashed [8] The Purpose of this work is to study about the 
microstructures, mechanical properties and wear characteristics of as cast silicon carbide (SiC) reinforced aluminum matrix composites (AMCs). AMCs of varying $\mathrm{SiC}$ content $(0,5,10$ and 20 wt. \%) were prepared by stir casting process. Microstructures, Vickers hardness, tensile strength and wear performance of the prepared composites were analyzed. The results showed that introducing $\mathrm{SiC}$ reinforcements in aluminum ( $\mathrm{Al}$ ) matrix increased hardness and tensile strength and 20 wt. \% SiC reinforced AMC showed maximum hardness and tensile strength. Microstructural observation revealed clustering and non-homogeneous distribution of $\mathrm{SiC}$ particles in the Al matrix. Porosities were observed in microstructures and increased with increasing wt. $\%$ of $\mathrm{SiC}$ reinforcements in AMCs. Pin-on-disc wear test indicated that reinforcing $\mathrm{Al}$ matrix with $\mathrm{SiC}$ particles increased wear resistance.

Mr. Prashant Kumar Suragimath, Dr. G. K. Purohit [9] In this study a modest attempt has been made to develop aluminium based MMCs with reinforcing material, with an objective to develop a conventional low cast method of producing MMCs and to obtain homogeneous dispersion of reinforced material. To achieve this objective stir casting technique has been adopted. Aluminium Alloy (LM6) and SiC, Fly Ash has been chosen as matrix and reinforcing material respectively. Experiment has been conducted by varying weight fraction of Fly Ash ( 5\% and $15 \%$ ) while keeping $\mathrm{SiC}$ constant $(5 \%)$. The result shown that the increase in addition of Fly Ash increases the Tensile Strength, Impact Strength, Wear Resistance of the specimen and decreases the percentage of Elongation. The microstructure study shows fairly uniform distribution of SiC and Fly Ash in LM6 based metal matrix composite.

S. Dhinakaran, T. V. Moorthy [10] The focus of the work is on fabricating the aluminium (AA6061) matrix composites reinforced with the varied propositions of the percentage of the weight of $\mathrm{B}_{4} \mathrm{C}$ particle of size at $220 \mu \mathrm{m}$ such as $3 \%, 6 \%$ and $9 \%$ by means of the stir casting method. The enhancement in the wettability of B4C particles in the matrix by adding K2TiF6 flux into the molten metal, has been significant. Besides, the microstructure and mechanical properties of the fabricated AMCs have also been analyzed. Uniform distribution of the presence of the $\mathrm{B}_{4} \mathrm{C}$ particle in the matrix has been confirmed using the Scanning Electron Microscope (SEM) images. It has been found that the tensile strength and hardness of the fabricated AMCs increases phenomenally with the increased content of the $\mathrm{B}_{4} \mathrm{C}$ particle.

J. David Raja Selvam, D. S. Robinson Smart, I. Dinaharan [11] This work focuses on the fabrication of AMCs reinforced with various weight percentages of $\mathrm{SiC}$ particulates and a constant weight percentage of Fly Ash by modified stir casting route. The wettability of $\mathrm{SiC}$ and Fly ash particles in the matrix was improved by adding magnesium into the melt. The microstructure and mechanical properties of the fabricated AMCs were analyzed. The optical and scanning electron micrographs revealed a homogeneous dispersion of both $\mathrm{SiC}$ and Fly ash particles in the aluminum matrix. The
SEM micrographs revealed that the addition of Fly Ash helped to prevent $\mathrm{SiCp}$ dissolution and the formation of $\mathrm{Al}_{4} \mathrm{C}_{3}$. The mechanical properties like hardness and tensile strength were improved with the increase in weight percentage of $\mathrm{SiC}$ particulates with constant weight percentage of Fly Ash in the aluminum matrix.

S. Rama Rao, G. Padmanabhan [12] In this context aluminium alloy - boron carbide composites were fabricated by liquid metallurgy techniques with different particulate weight fraction $(2.5,5$ and $7.5 \%)$. Phase identification was carried out on boron carbide by X-ray diffraction studies. Microstructure analysis was done with scanning electron microscope. Scanning electron microscopy images shows that boron carbide particles are uniformly distributed in aluminium matrix.

J. Babu Rao, D. Venkata Rao, N. R. M. R. Bhargava [13] In the present investigation, pure aluminium -5 to $15 \%$ (by weight) fly ash composites were made by stir casting route. Phase identification and structural characterization was carried out on fly ash by X- ray diffraction studies. Scanning electron microscopy and optical microscopy was used for microstructure analysis. There was a uniform distribution of fly ash particles in the matrix phase and also existing a good bonding between matrix and fly ash.

From the literature survey it is clear that the different combination of reinforcements used for the manufacturing of Hybrid Aluminium Metal Matrix Composite's (HAMMC). Hybrid Aluminium Metal Matrix Composite's (HAMMC) can be manufactured effectively by using an appropriate manufacturing technique depending on choice of reinforcement. Aluminium alloy with reinforcement is always better than base alloy because reinforcement particle's improves the mechanical properties like tensile strength, impact strength, wear resistance, hardness and corrosion resistance etc.

\subsection{Problem statement}

There are numerous studies has been reported on Aluminium Metal Matrix Composite reinforced with $\mathrm{B}_{4} \mathrm{C}$ or Fly Ash particles individually or with other combination but limited work is carried out on Aluminium reinforced with both Boron Carbide $\left(\mathrm{B}_{4} \mathrm{C}\right)$ \& Fly ash.Thus the present investigation has been focussed on utilization of waste Fly Ash and Boron Carbide $\left(\mathrm{B}_{4} \mathrm{C}\right)$ in useful manner by dispersing it in aluminium alloy matrix to manufacture $\mathrm{Al}-\mathrm{B}_{4} \mathrm{C}-\mathrm{Fly}$ Ash Hybrid Composites with different percentages of reinforcements, further the study of Wear \& Microstructural behavior of these Hybrid composites are also evaluated.

\section{MATERIALS \& METHODS}

\subsection{Materials}

Aluminium 7075 T651 is used as Matrix Material, Boron Carbide $\left(\mathrm{B}_{4} \mathrm{C}\right)$ \& Fly Ash powders are used as Reinforcement material.

\subsection{Experimental work}




\subsubsection{Stir Casting}

The simplest and most effective method used for the manufacturing of Hybrid Composites is the Stir Casting method. This Stir Casting technique is employed to manufacture is a Liquid state method and in this method a dispersed phase (reinforcement particles) is mixed with a molten metal by means of mechanical stirring. In this process Aluminium 7075 T651 (in proper wt \%) was placed in crucible and melted at 1000 . The reinforcements Boron Carbide $\left(\mathrm{B}_{4} \mathrm{C}\right) \&$ Fly Ash of proper $w \mathrm{t} \%$ were preheated to 500 in an Electric furnace to remove the moisture. The preheated reinforcements were slowly added to the molten metal at 1000 with continuous stirring by the stirrer for evenly dispersing Boron Carbide \& Fly Ash particles in the molten aluminium alloy. The high temperature Hybrid Aluminium Metal Matrix Composite (HAMMC) was poured in to the mould having inside mould dimensions of $250 \mathrm{~mm} \mathrm{X} 20 \mathrm{~mm}$ Diameter and left for some time to get solidified before withdrawing it from the mould. Three number of samples were manufactured having different composition (wt\%) as listed in the Table 1.

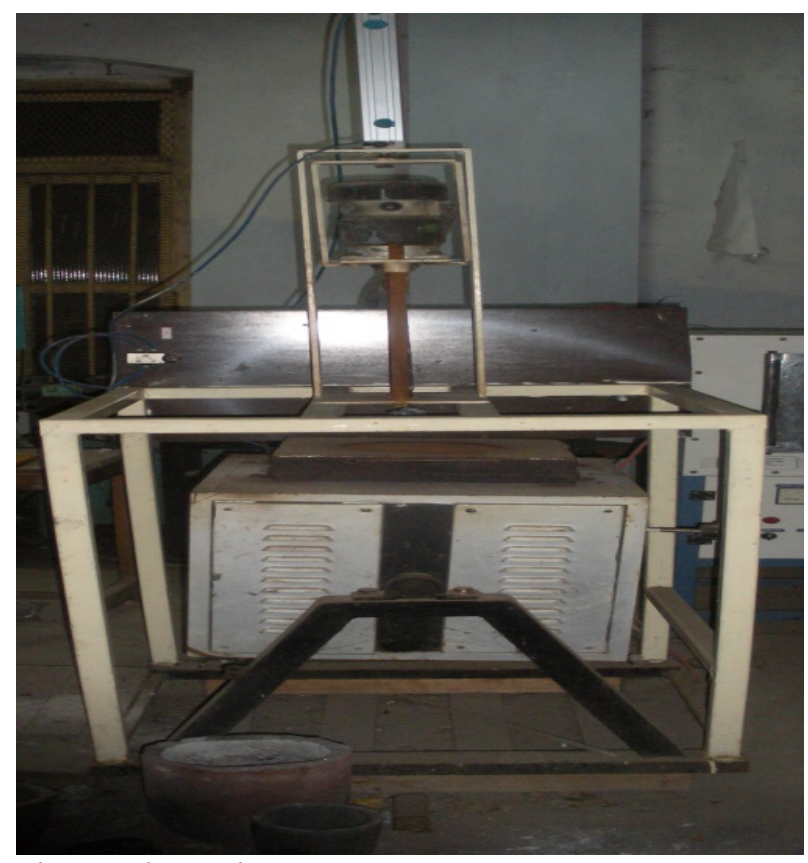

Fig. 1. Stir Casting Furnace

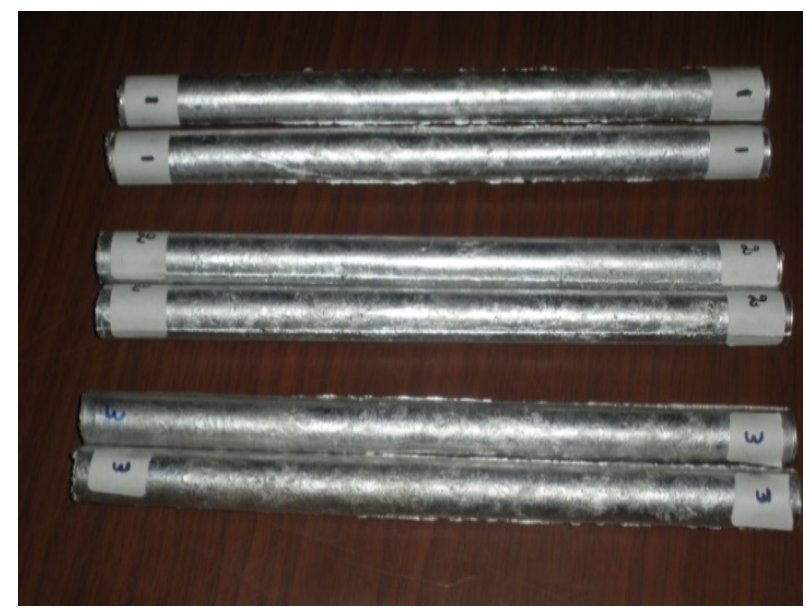

Fig. 2. HAMMC specimens after Stir Casting

\begin{tabular}{|c|c|c|}
\hline $\begin{array}{c}\text { Sl. } \\
\text { No. }\end{array}$ & $\begin{array}{c}\text { Materials with Compositions } \\
\text { (\% of Reinforcements) }\end{array}$ & $\begin{array}{c}\text { Sample } \\
\text { Number }\end{array}$ \\
\hline 1 & $\mathrm{Al}+1 \mathrm{wt} \% \mathrm{~B}_{4} \mathrm{C}+9 \mathrm{wt} \%$ Fly Ash & $\mathrm{S} 1$ \\
\hline 2 & $\mathrm{Al}+2 \mathrm{wt} \% \mathrm{~B}_{4} \mathrm{C}+8 \mathrm{wt} \%$ Fly Ash & $\mathrm{S} 2$ \\
\hline 3 & $\mathrm{Al}+3 \mathrm{wt} \% \mathrm{~B}_{4} \mathrm{C}+7 \mathrm{wt} \%$ Fly Ash & $\mathrm{S} 3$ \\
\hline
\end{tabular}

Table 1. HAMMC samples with their compositions

\subsubsection{SEM Sample Preparation}

Sample preparation plays an important and vital role in getting accurate results for the microstructure analysis. To study the Microstructure of the specimens were cut and prepared as per the standard metallographic procedure. The specimen is then polished with $\mathrm{SiC}$ abrasive papers of various grades. To give a scratch free surface, it is finally polished by using a disc polishing machine.After that the specimens were etched using Keller's reagent $(\mathrm{HCl}+\mathrm{HF}+$ $\mathrm{HNO}_{3}$ ). The microstructure of etched specimens were observed using Scanning Electron Microscope (SEM).

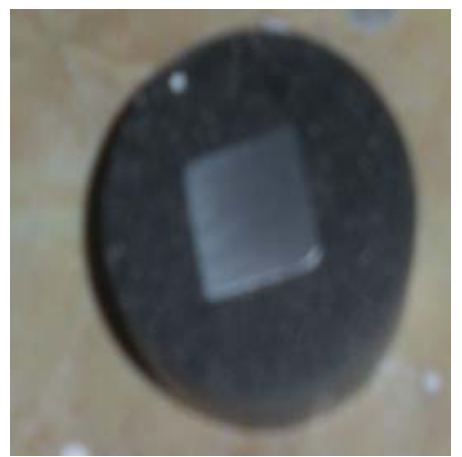

Fig. 3. Specimen for SEM Analysis

\subsection{TESTING OF HYBRID ALUMINIUM METAL MATRIX COMPOSITE}

The manufactured specimens were proposed to test for Waer Test \& also Microstructural analysis is going to be performed.

\subsubsection{Wear Testing:}

The Wear Testing of the Hybrid Aluminium Metal Matrix Composites (HAMMC) has been determined by Wear Testing Machine .

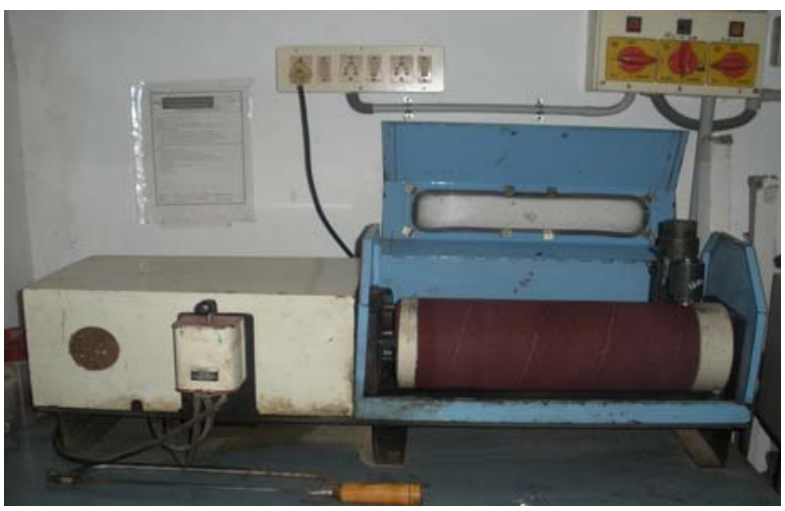

Fig. 4. Wear Testing Machine 


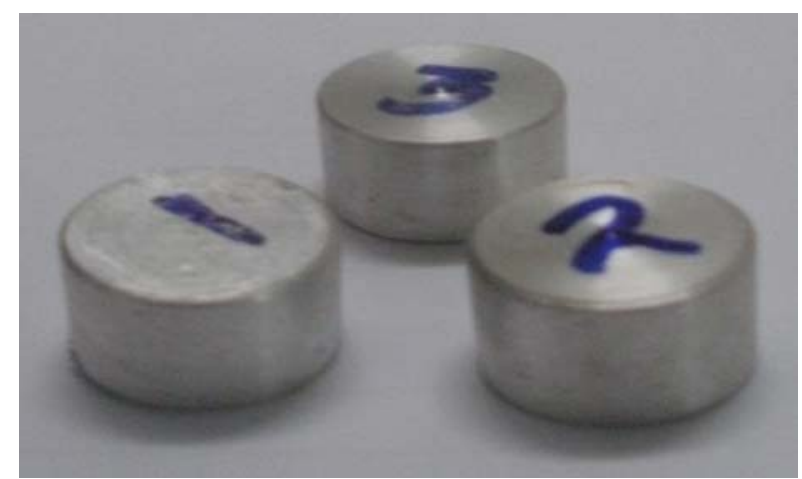

Fig. 5. Specimens before Wear Testing.

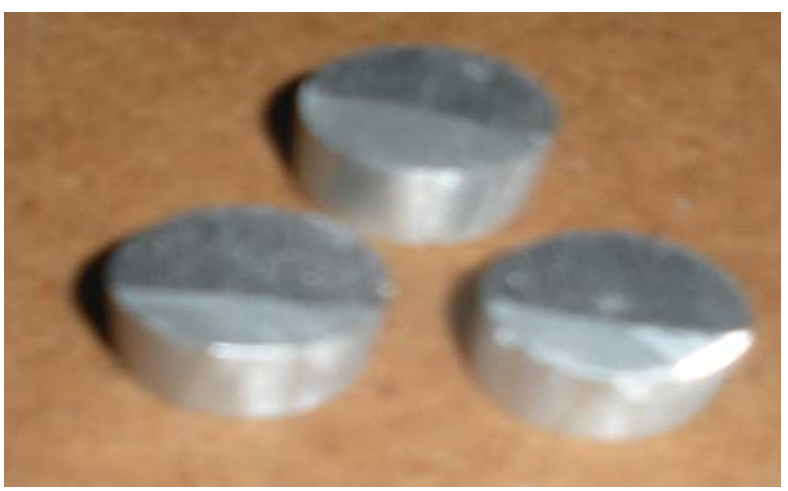

Fig. 6. Specimens after Wear Testing

\section{RESULTS \& DISCUSSIONS:}

\subsection{Wear Resistance:}

The test revealed that the Abrasion loss of the Hybrid Aluminium Metal Matrix Composite (HAMMC) was decreased gradually with the increase in the wt $\%$ of Boron Carbide powder. Table 2 shows the Wear Resistance of Hybrid Aluminium Metal Matrix Composite (HAMMC) at various percentages of Reinforcements $\left(\mathrm{B}_{4} \mathrm{C}+\right.$ Fly Ash).

Abrasion Lost $(\%)=\frac{(\text { Final Weight }- \text { Initial Weight })}{\text { Initial Weight }} \times 100$

\begin{tabular}{|c|c|c|c|c|}
\hline $\begin{array}{c}\text { Sample } \\
\text { Number }\end{array}$ & $\begin{array}{c}\text { Initial } \\
\text { Weight } \\
\text { (Gms) }\end{array}$ & $\begin{array}{c}\text { Final } \\
\text { Weight } \\
\text { (Gms) }\end{array}$ & $\begin{array}{c}\text { Abrasion } \\
\text { Loss } \\
\text { (Gms) }\end{array}$ & $\begin{array}{c}\text { Abrasion } \\
\text { Loss } \\
\text { (\%) }\end{array}$ \\
\hline S1 & 5.2974 & 5.1208 & 0.1766 & 3.33 \\
\hline S2 & 6.1777 & 6.0037 & 0.1740 & 2.82 \\
\hline S3 & 5.7123 & 5.5354 & 0.1769 & 3.09 \\
\hline
\end{tabular}

Table 2. Wear Resistance of HAMMC

\subsection{Evolution of Microstructure}

The Microstructural analysis of the specimen was carried out by using Scanning Electron Microscope (SEM). In general, SEM is used to observe the topography and morphology of a specimen. Th function of SEM is as a mapping device which probed by a beam of electron scanned across the surface.

A Scanning Electron Microscope (SEM) is a type of electron microscope that produces images of a sample by scanning it with a focused beam of electrons. The electrons interact with atoms in the sample, producing various signals that can be detected and that contain information about the samples surface topography and composition. The following figures i.e Figure 7 to Figure 21 shows the microstructures of the three samples (Sample 1, Sample $2 \&$ Sample 3) at different magnifactions .

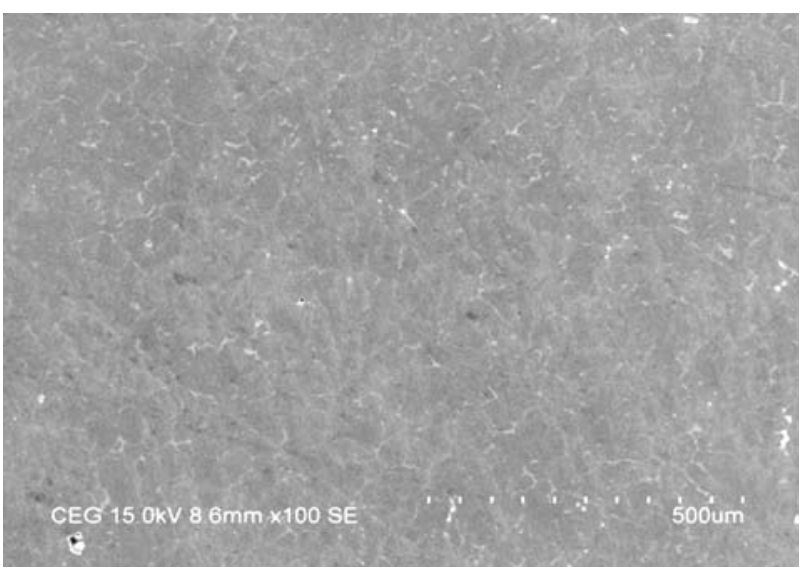

Fig. 7. Microstructure of Sample 1 at $100 \mathrm{X}$ Magnification

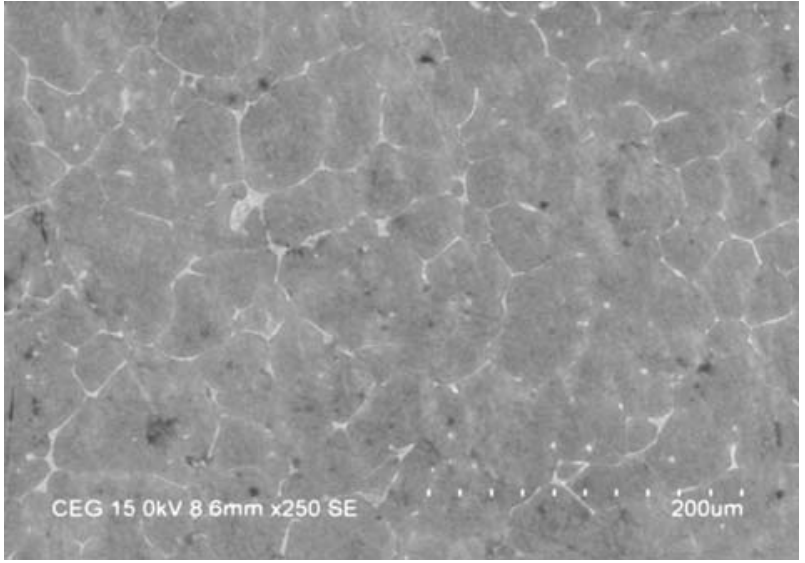

Fig. 8. Microstructure of Sample 1 at $250 \mathrm{X}$ Magnification

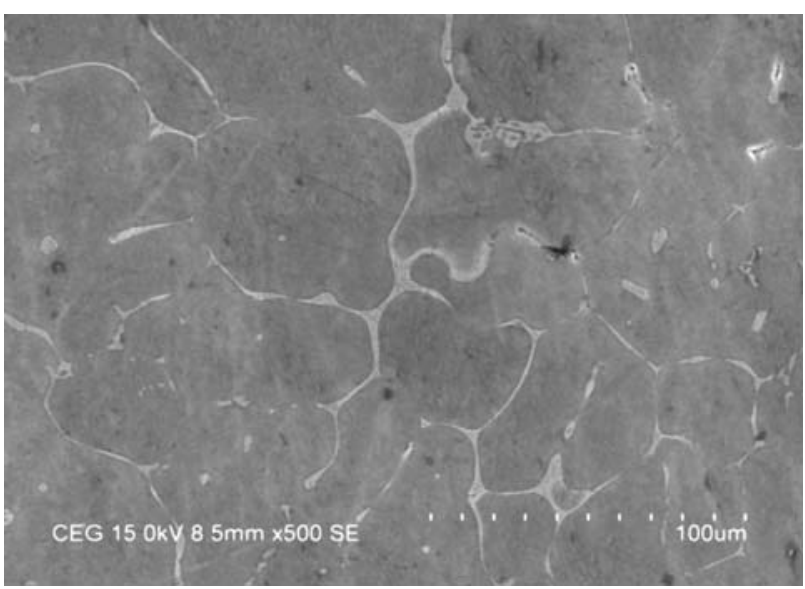

Fig. 9. Microstructure of Sample 1 at $500 \mathrm{X}$ Magnification 


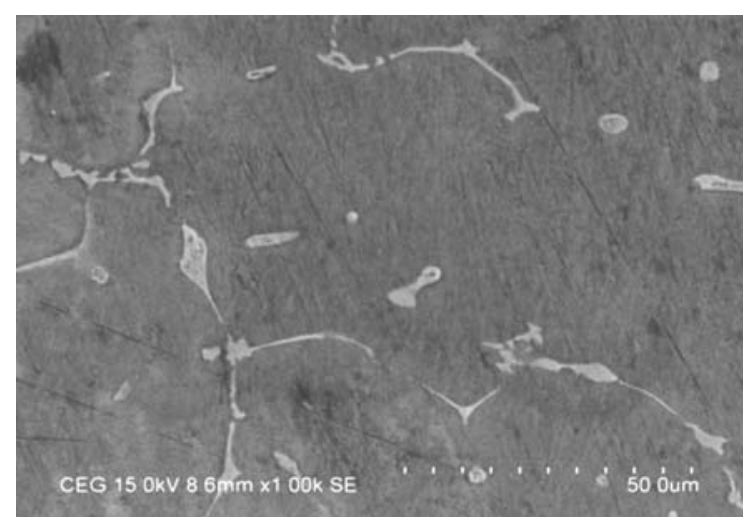

Fig. 10. Microstructure of Sample 1 at $1000 \mathrm{X}$ Magnification.

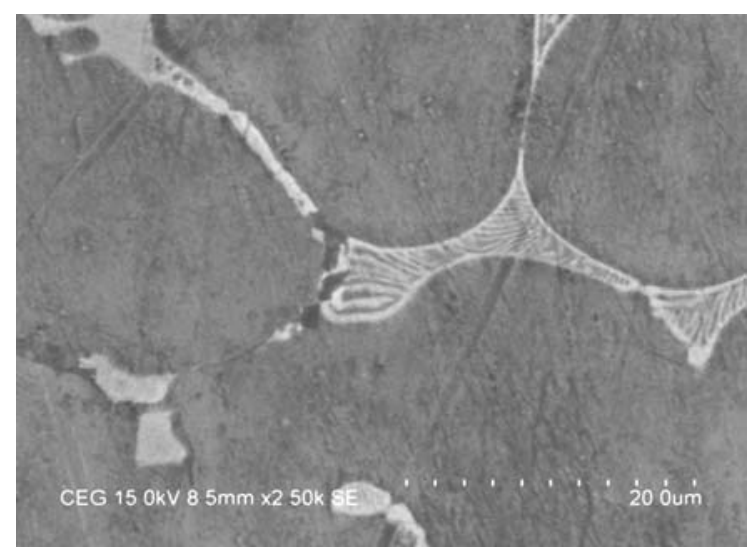

Fig. 11. Microstructure of Sample 1 at $2500 \mathrm{X}$ Magnification.

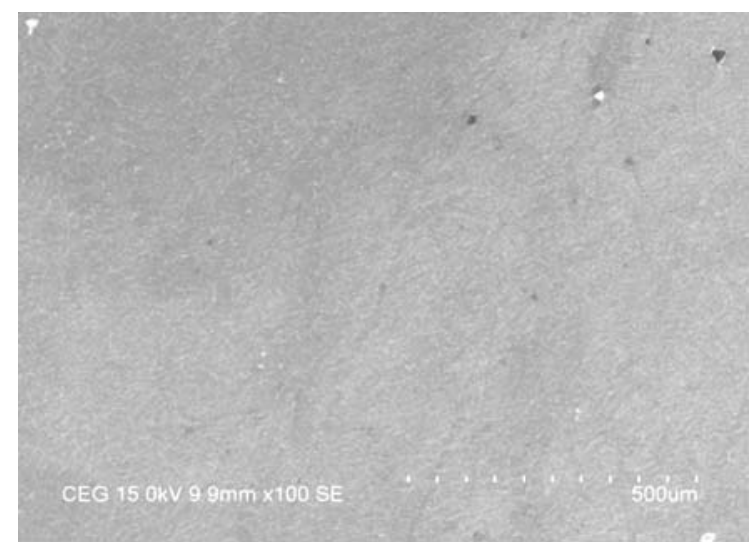

Fig. 12. Microstructure of Sample 2 at $100 \mathrm{X}$ Magnification.

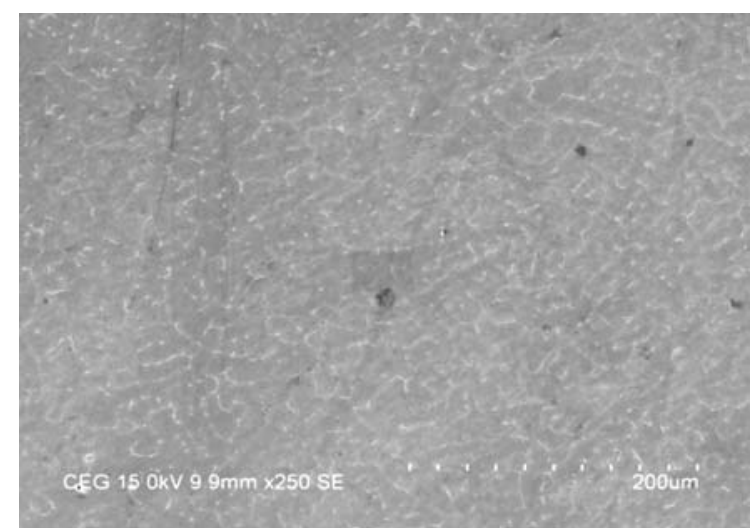

Fig. 13. Microstructure of Sample 2 at $250 \mathrm{X}$ Magnification.

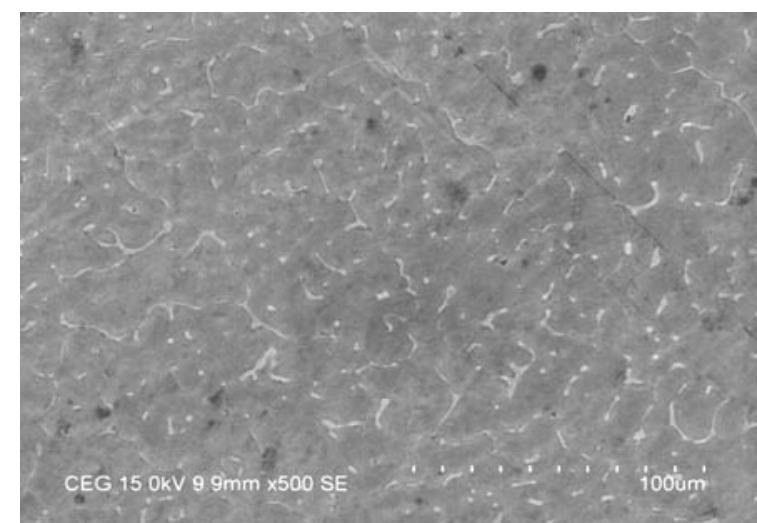

Fig. 14. Microstructure of Sample 2 at $500 \mathrm{X}$ Magnification.

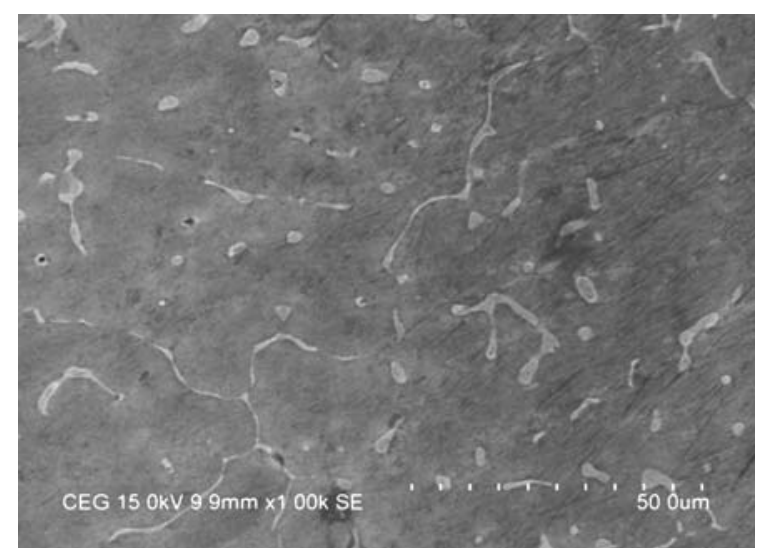

Fig. 15. Microstructure of Sample 2 at $1000 \mathrm{X}$ Magnification.

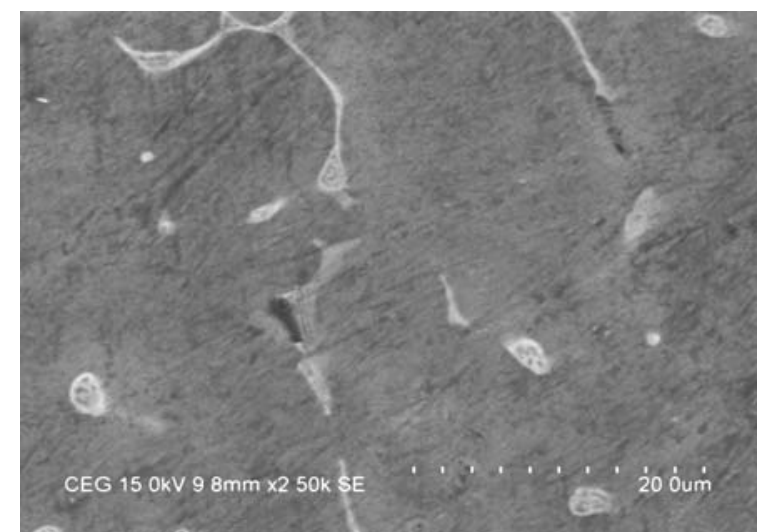

Fig. 16. Microstructure of Sample 2 at $2500 \mathrm{X}$ Magnification.

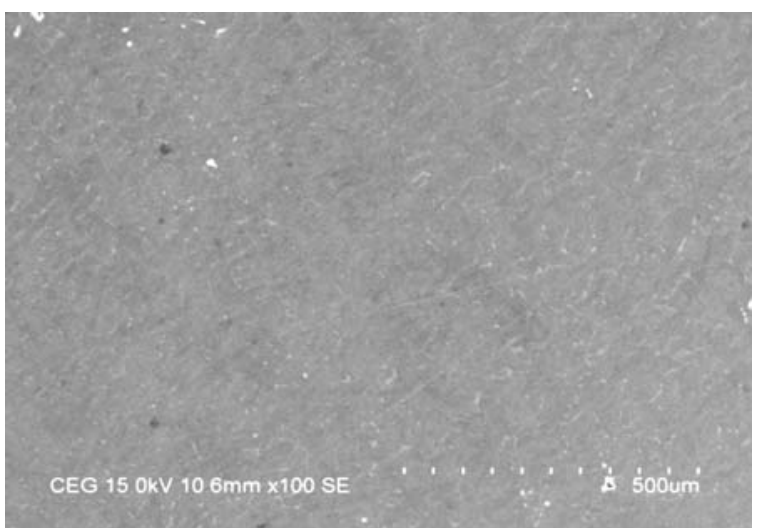

Fig. 17. Microstructure of Sample 3 at $100 \mathrm{X}$ Magnification. 


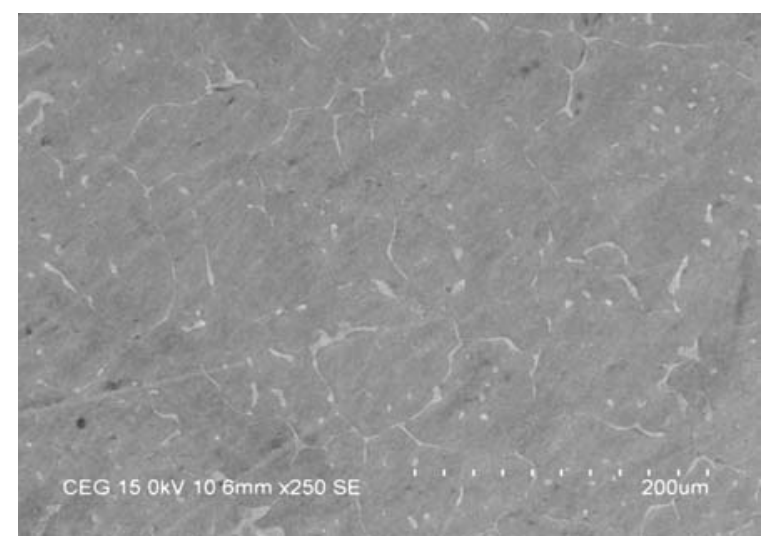

Fig. 18. Microstructure of Sample 3 at $250 \mathrm{X}$ Magnification.

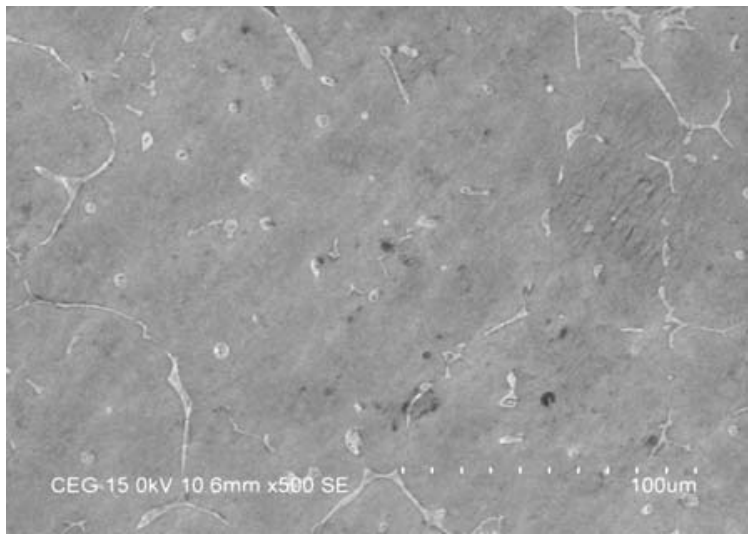

Fig. 19. Microstructure of Sample 3 at $500 \mathrm{X}$ Magnification.



Fig. 20. Microstructure of Sample 3 at 1000 X Magnification.

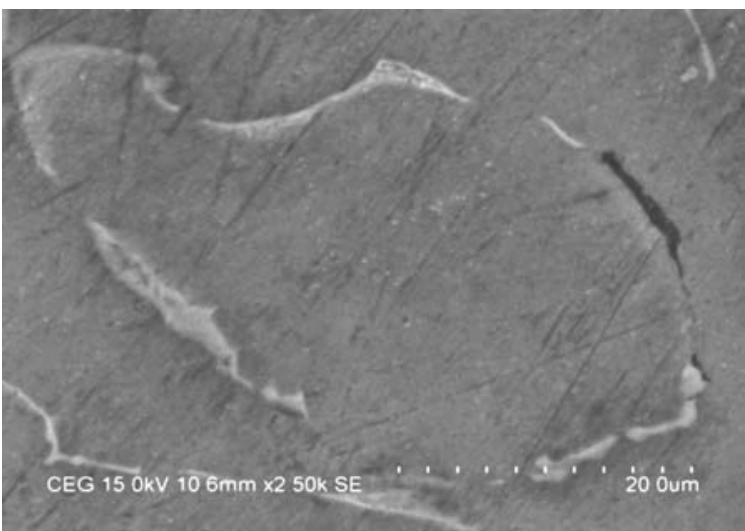

Fig. 21. Microstructure of Sample 3 at 2500 X Magnification.

\section{CONCLUSIONS}

The Hybrid Aluminium Metal Matrix Composite (HAMMC) was produced with different $\mathrm{Wt} \%$ of Reinforcements i.e Boron Carbide $\left(\mathrm{B}_{4} \mathrm{C}\right)$ \& Fly Ash. The Wear \& Microstructural Properties of the Hybrid Aluminium Metal Matrix Composite (HAMMC) were evaluated and the following conclusions are drawn from the study:

1) The Hybrid Aluminium Metal Matrix Composite (HAMMC) was successfully fabricated by Stir Casting Technique.

2) The test revealed that the Abrasion loss of the Hybrid Aluminium Metal Matrix Composite (HAMMC) was decreased gradually with the increase in the $\mathrm{wt} \%$ of Boron Carbide powder. Also the Hybrid Aluminium Metal Matrix Composite with $2 \%$ Boron Carbide $\left(\mathrm{B}_{4} \mathrm{C}\right)$ and $8 \%$ Fly Ash is having less Abrasion loss indicating that it posses High Wear Resistance.

3) The SEM micrographs revealed the presence of Boron Carbide \& Fly Ash and also shows a homogenous distribution of Boron carbide \& Fly Ash Particles in the Aluminium matrix material.

\section{REFERENCES}

[1] E.Subbarao and N.Ramanaiah, Microstructure and Mechanical properties of $\mathrm{Al}-\mathrm{Mg}-\mathrm{Si}$ based metal matrix composites reinforced with $B_{4} C$ particles produced through Stir Casting processes, Journal of Production Engineering, Vol.19(1), 2016, 75 - 80.

[2] N.Venkat Kishore and Dr.K.Venkata Rao, Mechanical properties in MMC of aluminium alloy (A356/LM25) matrix and boron carbide $\left(B_{4} C\right)$ reinforcement, International Journal of Engineering Research \& Technology (IJERT), Vol.5, Issue 02, February-2016, 683-689.

[3] M.D.Antony Arul Prakash and M.Arockia Jaswin, Microstructural analysis of aluminium hybrid metal matrix composites developed using stir casting process, International Journal of Advances in Engineering, Vol.1(3), 2015, P.P:333-339.

[4] Gaurav Mahajan, Nikhil Karve, Uday Patil, P.Kuppan and K.Venatesan, Analysis of microstructure, hardness and wear of Al-SiCTiB2 hybrid metal matrix composite, Indian Journal of Science and Technology, Vol 8(S2), January 2015, P.P: 101-105.

[5] Amardeep Singh, Ajay Singh Rana and Niraj Bala, Study of wear behaviour of aluminium based composite fabricated by stir casting technique, International Jounal of Mechanical Engineering and Robotics Research, Vol. 4, No.1, January 2015, 271-278.

[6] T.Raviteja, N.Radhika and R.Raghu, Fabrication and mechanical properties of stir cast Al$\mathrm{Si} 12 \mathrm{Cu} / \mathrm{B} 4 \mathrm{C}$ composites, International Journal of Research in Engineering and Technology, Volume 03, Issue 07, Jul-2014, P.P:343-346. 
[7] T.Thirumalai, R.Subramanian, S.Kumaran, S.Dharmalingam and S.S.Ramakrishnan, Production and characterization of hybrid aluminium matrix composites reinforced with boron carbide $\left(B_{4} C\right)$ and graphite, Journal of Scientific \& Industrial Research, Vol.73, October 2014, P.P:667-670.

[8] Md.Habibur Rahman, H.M.Mamum Al Rashed, Characterization of silicon carbide reinforced aluminium matrix composites, 10th International Conference on Mechanical Engineering ICME 2013,Procedia Engineering 90(2014), P.P:103109.

[9] Prashant Kumar Suragimath, Dr.G.Purohit, $A$ study on mechanical properties of aluminium alloy(LM6) reinforced with $\mathrm{SiC}$ and fly ash, IOSR Journal of Mechanical and Civil Engineering, Volume 8, Issue 5, Sep-Oct 2013, P.P:13-18.

[10] S.Dhinakaran and T.V.Moorthy, Fabrication and characteristic of boron carbide particulate reinforced aluminium metal matrix composites.

[11] David Raja Selvam, D.S.Robinson Smart, I.Dinaharan, Synthesis and characterization of Al6061-Fly AshP-SiCP composites by stir casting and compocasting methods, 10th Eco-Energy and Materials Science and Engineering (EMSES2012), Energy Procedia 34 (2013), P.P:637-646.

[12] Rama Rao and G. Padmanabhan, Fabrication and mechanical properties of aluminium-boron carbide composites, International Journal of Materials and Biomaterials Applications 2(3), 2012,P.P:15-18

[13] J.Babu Rao, D.Venkata Rao and N.R.M.R.Bhargava, Development of light weight ALFA composites, International Journal of Engineering Science and Technology, Vol.2, No.11, 2010, P.P:50-59.
Authors: Bandaru Sivakumar, P.G.Student, Advanced Manufacturing Systems, Department of Mechanical Engineering, Sri Venkateswara College of Engineering, Tirupati, Chittoor District, Andhrapradesh, India.

Pudi Chran Theja, Assistant Professor, Department of Mechanical Engineering, Sri Venkateswara College of Engineering, Tirupati, Chittoor District, Andhrapradesh, India.

E-mail: bsivatpt@gmail.com pcttej1@gmail.com 